Journal Universitas Muhammadiyah Gresik Engineering, Social Science, and Health International Conference (UMGESHIC)

UMGCINMATIC : $1^{\text {st }}$ Rethinking Education during Covid-19 Era: Challange and Innovation

\title{
Legal Protection Against Song Covers in Snack Video Applications Judging from Law Number 28 of 2014 concerning Copyrights
}

\author{
Author \\ Muhammad Lukman Alghofiki, Hardian Iskandar, Dodi Jaya Wardana \\ University of Muhammadiyah Gresik \\ Email: alfiki43@gmail.com
}

\begin{abstract}
The emergence of copyright infringement in various forms and types, both in quantity and quality, one of which is the work of art in the field of music is an attitude of disrespecting the work of others. The proliferation of song multiplication in Indonesia has caused a lot of pressure from developed countries to the Indonesian government to try harder to enforce the law in the field of intellectual property. The problem in this writing is related to the form of violation of the song cover on the Snack Video application and the form of legal protection against the cover song on the Snack Video application. This research uses normative juridical research, which examines the laws and regulations related to the subject matter. experts, legal cases, mass media, internet social media, and legal journals. The results showed the form of violation of the cover song on the Snack Video application, namely multiplication. The form of legal protection is carried out by means of prevention (preventive) and resolution (repressive). Even though the government has taken many actions, the efforts made by the Indonesian government to protect copyrighted works have not yielded maximum results.
\end{abstract}

Keywords: Copyright Infringement, Legal Protection, Copyright Law 


\section{INTRODUCTION}

Intellectual Property has benefits for every individual with the power of intellectual ability to produce a work that will be protected by law, for example in the field of Copyright. Copyright is an exclusive right owned by the creator as the Copyright holder to regulate his work or give permission to other parties to do something to the work but within the limits of the law that is currently in effect.

Copyright is part of Intellectual Property whose scope of object is protected more broadly than other parts of IP, because it includes science, art and literature which also includes computer programs. The development of Indonesia's creative economy is one of the guarantees for the rapid development of information and communication technology that requires reform of copyright laws by making copyright an important part of the country's creative economy. Even if intellectual property doesn't show the real thing. It is not a material object, but the result of the creative activity of the human brain, which is revealed to the outside world in both material and immaterial forms.

Copyright is part of Intellectual Property whose scope of object is protected more broadly than other parts of IP, because it includes science, art and literature which also includes computer programs. Intangible property rights are not the substance or form of an object or property because the subject of rights is an intangible object. Even if intellectual property doesn't show the real thing. It is not a material object, but the result of the creative activity of the human brain, which is revealed to the outside world in both material and immaterial forms.

Over time, this has encouraged Indonesia's creative economy to grow. One of them is the world of art, which contains songs that can not only be enjoyed on television and radio, but also on the Internet, which require legal protection for their works. In this modern era to enjoy a song is very easy due to the development of technology that is so fast and sophisticated that listening to songs can be done via the internet. The development of technology to listen to a song certainly has a positive or negative impact.

In this modern era to enjoy a song is very easy due to the development of technology that is so fast and sophisticated that listening to songs can be done via the internet. The development of technology to listen to a song certainly has a positive or negative impact. The positive impact is that it is easier for people to listen to songs and for songwriters it is easier to promote their work, while the negative is that many people abuse technological advances for their personal interests, namely by seeking money in the form of making videos that cover songs and upload them to several media sites. social. 
One of the social media on smartphones that uploads song covers such as the Snack Video application where users can freely upload videos along with song covers that they unknowingly use as covers in a video clip without permission from the creator. Indonesia is a country that supports legal certainty and copyright protection, so that it is not misused for someone's benefit. With legal certainty for creators, copyright infringement can be minimized.

\section{RESEARCH METHODS}

The type of research used is normative juridical law research, namely research that examines laws and regulations that are related to the object of research studies, especially regarding legal principles and norms contained in legislation. In this study, the research approach used is the Statute Approach and the Conceptual Approach. The compiler uses legal materials obtained from library data. In addition, the types of legal materials used are primary legal materials and secondary legal materials. Primary legal materials, namely legal materials that are authoritative in nature, made by authorized officials include statutory regulations such as the 1945 Constitution of the Republic of Indonesia, the Civil Code, Law Number 28 of 2014, concerning Copyrights and Explanation Secondary legal materials, namely legal materials that explain primary legal materials which include literature books, expert opinions, legal cases, mass media, social media, internet, and legal journals.

The collection of legal materials used in the preparation of this thesis went through several steps, namely the collection of legal materials from the literature in the form of law and literature according to the subject of the study, eliminating irrelevant ones, determining legal

problems to be solved, analyzing the proposed legal issues, drawing conclusions in the form of opinions. . As for the legal materials obtained from the collection of legal materials, the compilers describe and relate them in such a way, so that they are presented in a systematic explanation. It aims to answer the legal problems that have been formulated. The way of processing legal data is a conclusion. In other words, it draws conclusions from a general problem to a specific problem.

\section{RESULT AND DISCUSSION}

Forms of Violation of Song Covers in the Snack Video Application

This Law explains that Copyright is the exclusive right of the creator and is automatically created according to the principle of claim after the creation becomes real without reducing the restrictions set by the Law. where the right is assigned to the creator. The term Copyright itself is a translation of the Dutch language Auteursrecht. The Copyright Law has 
regulated who is considered the creator, as in Article 31 of the Copyright Law, "Those who are considered as the Creator are the person whose name is claimed on the work, declared to be the Creator of a work, mentioned in the creation registration letter, and/or listed in the general register of creation to be the Creator".

Based on the object, Copyright is divided into the scope of Copyright as regulated in Article 40 of the Copyright Law, which includes books, pamphlets, published works of art, and all other written works; Lectures, lectures, speeches, and other similar creations; Props made for the benefit of education and science; Songs and/or music with or without subtitles; Drama, musical drama, dance, choreography, wayang, and pantony; Works of art in all forms such as paintings, drawings, carvings, calligraphy, sculptures, sculptures or collages; Applied works of art; Architectural works; Map; Batik art or other motif art; photographic works; Portrait; Cinematographic works; Translation, interpretation, adaptation, anthology, database, adaptation, arrangement, modification, and other works resulting from the transformation; Translation, adaptation, arrangement, transformation, or modification of traditional cultural expressions; Compilation of creations or data, both in a format that can be read by computer programs or other media; The compilation of traditional cultural expressions during the compilation is an original work; video games; computer programs.

Some works that are not protected by the provisions of the copyright law are works that have not been created in a certain form and are solely in the form of creative ideas. Technical issues or the format is for functional purposes only. In addition, there is no copyright in the works of public meetings of state institutions, laws, speeches or speeches of government officials, decisions of justice or orders of judges, and the consequences of scriptures or religious symbols.

As Exclusive Rights, Copyright includes Moral Rights and Economic Rights. Moral rights are a form of public acknowledgment or appreciation to the creator for his creative expression. Moral rights are rights that are eternally attached to the creator. Because moral rights cannot be transferred as long as the creator is still alive, but the exercise of these rights can be transferred by will or other reasons in accordance with the provisions of the legislation after the author dies. Moral rights contain two components, namely the right of attribution, this right requires the identity of the creator to be attached to the work, either under his own name or in a pseudonym. And the Right of Integrity, this right is the most important is the personal image and credibility given to the creator.

It can be seen that moral rights are rights that are only owned by the Author over his/her creation, where the right cannot be transferred as long as the Author is still alive, and can be transferred after the Author dies as stipulated in the Copyright Law. With this right, any changes 
in any form to the work of creation must obtain permission from the creator of the work, if other people make changes without permission, the author can take legal action.

Economic Rights are the exclusive rights of the Author or Copyright Holder to obtain economic benefits from the work. Economic rights (economic rights) on a Work are owned by the Copyright holder, namely the Creator himself or another party who is granted the right. This right includes all economic benefits that can be obtained from the announcement and/or reproduction of the Works. Authors have the right to publish works which are divided into three types, namely the right to publish or publish (right to publish), the right to perform (right to perform), and the right to distribute (right to distribute).

The creator also has the right to reproduce which is divided into two kinds of rights, namely the right of reproduction and the right of adaptation. This right of reproduction is related to the reproduction or reproduction of the work. This right is also known as a mechanical right because it involves mechanical technology that allows reproduction of works. Reproduction means the use of the same or different materials, including permanent or temporary transfer, to augment the whole or a very important part of the work. Adaptation rights, adaptation activities include the act of reproduction, especially the act of transforming the form and media of expression of the work. However, the adaptation work and the creator of the adaptation work can be protected by Copyright as long as the adaptation activity is with the permission of the original Creator. Authors have the right to adapt their own works which include translating activities.

Song Covering is the act of bringing back songs or arranging songs that have previously been recorded and sung by other musicians or singers. Coverage can be said if it consists of several elements that must be met, namely the result of a new recording, performing a song by another singer, adding certain creative contributions such as adding rhythm or arrangement, and rearranging musical notation.

Copyright infringement is the use of copyrighted work that violates the exclusive rights of the copyright holder, such as the right to reproduce, reproduce, distribute, display copyrighted works or create derivative works without the permission of the creator or copyright owner of the work. These activities include, among others, exploitation (announcement, copying and distribution) for commercial purposes or not for commercial purposes of a copyrighted work without first asking permission or obtaining a license from the creator, replacing or changing the name of the creator in his creation without the consent of the owner. Copyright, replacement or change of title of a work without the consent of the creator, the existence of provisions that are detrimental to the Indonesian economy in the license agreement. 
It can be seen that the form of violation of the cover of the song in the Snack Video application is the doubling of the song in the form of multiplying the video content on the cover of other people's songs without the permission of the songwriter. Digital copyrights are very easy to copy, and the consequences of infringement are almost indistinguishable from the original. Not only that, people can then make changes to the copying results to various countries without spending any money. This makes it easier for anyone to commit a large-scale infringement, but on the other hand, it is very difficult for the copyright owner to know that an infringement has occurred and to take legal action. Not only Snack Video Application users enjoy the results of this violation, but all social media users can also enjoy it, because of the content sharing and downloading features in the application.

This form of violation violates Article 9 paragraph (1) letter b, namely "copying creations in all forms". Where the right to reproduce is intended for the Creator or Copyright Holder as regulated in the Copyright Law, so every exercise of economic rights must obtain permission from the Creator or Copyright Holder. In essence, copyright infringement occurs when someone other than the creator or copyright holder exploits their creation, in other words, that person uses the exclusive rights of the creator or copyright holder.

The author uses one of the videos uploaded by a Snack Video application user who has the ID "Saalhaerid" as an example of a form of copyright infringement, where in the video it has covered a song belonging to musician Ade Nurulianto as a songwriter and sung by Astrid Sartiasari, the song is the song "About Flavor". The cover of the song does not include the name of the creator, but the uploader states that the cover of the song is his own voice. This form of violation is also called mechanical right because it relates to machine technology that can reproduce the work. the use of copies of such works increases the number of works in their entirety or in very important parts using the same or different materials, including permanent or temporary transmissions.

Article 113 paragraph (3) of the Copyright Law, "Every person who without rights and/or without permission of the Author or Copyright holder violates the economic rights of the Author as referred to in Article 9 paragraph (1) letter a, letter b, letter e, and/or letter g for Commercial Use shall be sentenced to a maximum imprisonment of 4 (four) years and/or a maximum fine of Rp. 1,000,000,000.00 (one billion rupiah)".

The article above states that anyone who does not have the right to a work that has been realized intentionally or unintentionally violates the economic rights of another person's creation commercially will be subject to criminal sanctions. The criminal sanction is in the form of imprisonment for a maximum of 4 years in prison and/or a maximum fine of Rp. $1,000,000,000.00$ (one billion rupiah). The intended commercial use is the use of Works and/or 
Related Rights products with the aim of obtaining economic benefits from various sources or for a fee. Thus, the author does not include the name of the Creator in his work and acknowledges that the work is his work and uploads it so that many other users of the Snack Video Application see it and share it, causing Copyright infringement.

Forms of Legal Protection Against Song Covers on Snack Video Applications

Understanding Law according to J.C.T Simorangkir, Law is the rules that is coercive, which determines human behavior in the community environment made by authorized official bodies, which violation of these regulations results in taking action, namely with certain punishments. According to the Legal Dictionary, the definition of law is a regulation made by a public body that has the power to determine the behavior of an obsessive society and a law enforcement officer who can take action when necessary. According to Satjipto Raharjo, the law protects a person's interests by allocating a power to him to act in the context of his interests. The distribution of these forces is measured in terms of the width and depth specified. It is said that such power is true. However, not all power in society is a right, but only certain powers bind it to people.

One of the characteristics and at the same time the purpose of the law is to provide protection (protection) to the community. Therefore, the legal protection of the community must be obtained in the form of legal certainty. Legal protection is the government's effort to protect the public from injustice between individuals or businesses in accordance with applicable law. Legal protection is a form of community service. According to Philipus M. Hadjon, legal protection is the protection of the dignity and worth, as well as the recognition of the human rights possessed by legal subjects based on general provisions of sewangan or as a collection of rules or rules that will be able to protect something else. With regard to consumers, it means that the law provides protection of customer rights from something that results in the nonfulfillment of these rights.

The protections available to consumers vary and can take the form of economic, social and political protections. Consumer protection is paramount and the topic of this discussion is legal protection. Legal protection is one of the main forms of protection because it is based on the idea that the law is a means that fully embraces the interests and rights of consumers. In addition, mandatory laws and regulations that are officially recognized by the state can be applied permanently. In contrast to protection through other institutions such as economic or political protection, for example, which is temporary or temporary. 
The presence of law in human life aims to maintain and oversee existing interests so that conflicts of interest can be minimized as much as possible. So that by suppressing the conflict of interest, the rights inherent in each individual can be protected and achieved. Legal provisions and all regulations made by the community are basically an agreement by the community to regulate behavioral relations between members of the community and between individuals and the government which are considered to also represent the interests of the community.

Intellectual Property Legal Protection is needed, there are rights born from human creative intelligence that are carried out in real work, so protection from the Copyright Law is needed. Creation sacrifices time, money, effort, and thought when creating a work. If the protection of the work is not provided, it will facilitate the imitation by other parties freely which is certainly detrimental to the Creator. This protection is an award for someone who has poured his idea into a work.

According to Philipus M. Hadjon, there are two kinds of legal protection facilities, namely preventive legal protection and repressive legal protection. This preventive protection, legal subjects have the opportunity to challenge and comment on government decisions. The goal is to avoid conflict. Preventive legal protection is essential for government action based on freedom of action. Because preventive legal protection is motivated to be careful when making decisions at the discretion of the government.

Repressive legal protection to resolve disputes, The treatment of legal defense by the general courts and the Indonesian administration is included in this category of legal defense. The principle of legal protection in the administration of government is based on and rooted in the concept of recognizing and protecting human rights, since historically the concept of recognizing and protecting human rights was introduced in the West, imposing obligations on society and the government. The second principle underlying the just defense of government action is the rule of law. With regard to the recognition and protection of human rights, the recognition and protection of human rights occupies an important place and can be linked to the objectives of the rule of law.

The law states that songs are copyrighted works, even if they are made with or without text. It is clear that the scope of works protected by copyright law includes songs. If you treat copyright like property, you need to protect it. This protection is provided by copyright in order to stimulate or inspire the activity of its creator. The law provides a clear definition of the author, the protected work, and the rights associated with the author.

Intellectual Property Protection has its own urgency. The urgency is that all intellectual works will be protected. The meaning of the word protected here correlates with three legal 
purposes. First, legal certainty means that the protection of intellectual property rights makes it clear who actually owns the intellectual work. Second, for benefit, intellectual property protection is very beneficial for copyright owners, in the form of royalties. Third, justice can benefit the holder, especially in the form of increasing income and the ability of the state to increase foreign exchange.

The service provider, namely the Snack Video Application, does not have legal protection against song covers on the Snack Video application in any form of violation, because the settings for Snack Video do not fulfill the elements of legal protection. Then the legal relationship between Copyright violators and the Creator or Copyright Holder whose rights are violated arises because of the Act. Copyright Legal Protection for song composers has been regulated in Law Number 28 of 2014 concerning Copyright.

The freedom of covering songs on the Snack Video Application can create new Copyright violators every day, because the application does not provide Intellectual Property for the content uploaded by its users. Songs can be very financially helpful because everyone tends to copy and control the work of others, which is a right associated with the creator or copyright owner and/or the owner of related rights that can be detrimental. Related rights holders are those who are involved in copyright, namely the exclusive rights of actors, record makers and broadcasters.

The form of legal protection against song covers on the Snack Video application can take two forms. First, the form of preventive legal protection. This protection is specifically intended to prevent copyright infringement related to the act of covering songs. This protection is contained in CHAPTER X of Law Number 28 of 2014 concerning Copyright which regulates the Registration of Works and Related Rights Products. The Minister as the organizer of the registration and deletion of related Copyright Works and Products is the Ministry of Law and Human Rights.

The application for registration of the work is submitted in writing by the Author, the owner of the Related Rights, or his Proxy which is carried out online or offline to the Minister of Law and Human Rights by attaching the work and attaching a statement of ownership of the Works as well as paying a predetermined fee. Applications submitted by several people against their work are required to write down all the names of the applicants with one address and attach a statement to prove the rights or legal entities must attach the original copy of the legal establishment deed. For foreign national applicants, the application must not be made alone but must go through a valid Intellectual Property consultant as his proxy. After the Minister receives the application, the minister will issue a Letter of Registration of Works and record the Works in the general register of Works. The recording of Works or Related Rights 
products in the general register of Works is not an endorsement of the contents, meaning, intent, or form of the Works or Related Rights products that are recorded.

In accordance with the principle of the birth of copyright that copyright is the exclusive right of the creator to reproduce automatically, in principle if the author does not allow then the arranged song is not protected by copyright. It is declared after the creation is realized in a concrete form, without any restrictions regulated by law. Article 40 Paragraph 2 of the Copyright Law stipulates that a work is a different creation without affecting the copyright of the original work. Permission is obtained from the songwriter, copyright owner, original owner. Copyright does not automatically arise when a work is created but violates the law, namely violating the copyright of another person or party.

Protected works do not have to go through a process of recording in Intellectual Property or called registration, but it would be better if they were registered because they are profitable for the creator. For this reason, if there is an imitation of the work, the Creator can easily prove it because there is written evidence that lists the creation. Further provisions in CHAPTER X of Law Number 28 of 2014 are regulated in Government Regulation Number 16 of 2020 .

Second, the form of repressive legal protection, namely resolving disputes that have occurred through arbitration (court) with civil claims and/or criminal prosecutions submitted to the District Court. This legal protection is contained in CHAPTER XIV of Law Number 28 of 2014 concerning Copyright which regulates Dispute Resolution. Dispute resolution, a problem occurs when a dispute arises between two parties, either the creator, copyright owner or related rights holder, who are not satisfied with the work in question. The law directs that the settlement of the dispute can be through Arbitration or the Commercial Court.

Article 99 paragraph (1) of the Copyright Law, "Creators, Copyright Holders, or Related Rights owners have the right to file a claim for compensation to the Commercial Court for Copyright Infringement or Related Rights products". The paragraph states that the Creator, Copyright Holder, or Related Rights owner has the right to claim compensation due to Copyright infringement, where the claim is submitted by the plaintiff or his legal representative to the Commercial Court.

The lawsuit submitted to the commercial court will be registered with the clerk since the lawsuit is registered, the clerk will provide a receipt as proof of registration. The court will set a maximum trial day of 4 days since the lawsuit is registered, and notification and summons of the parties will be made by the bailiff a maximum of 7 days after the lawsuit is registered. The decision related to the lawsuit must be notified in a general session a maximum of 90 days 
from the registration of the lawsuit, it can be extended by 30 days with the approval of the chairman of the Supreme Court. And the decision must be delivered by the bailiff to the parties a maximum of 14 days after the decision is notified. Thus the preventive and repressive protection that has been stated in Law Number 28 of 2014 is a guideline for resolving cases that have not been or have been in dispute if there are cases related to Song Covering

\section{CONCLUSION}

Based on the results of research and discussion of legal protection against song covers in the Snack Video application in terms of Law Number 28 of 2014, we can conclude that The form of violation of the cover of the song in the Snack Video application is doubling in the form of multiplying the songs covered in a video content. This violation was carried out by the uploader intentionally so that the video on the cover of the song can be accessed by the public for the benefit of the uploader. Uploader does not get permission or provide royalties to Related Rights Holders. Forms of Legal Protection for Song Covers in the Snack Video Application, namely Preventive Legal Protection and Repressive Legal Protection. Preventive legal protection, namely regarding the procedures for the registration of works and related rights products. This protection can be used to prevent disputes from occurring. The application for registration is submitted in writing in Indonesian to the Minister of Law and Human Rights. Besides that, getting protection does not have to go through the recording of the creation, but this recording will make it easier for the Creator to prove that the creation is his creation. Repressive legal protection is the procedure for resolving disputes through arbitration or commercial courts. There are two options in this protection, namely civil lawsuits and/or criminal charges.

\section{REFERENCES}

Hamzah, Margono. 2000. Undang-Undang Hak Cipta Di Indonesia Yang Telah Diperbaharui. Jakarta : Sinar Graflka.

Hutauruk, M. 1982. Pengaturan Hak Cipta Nasional. Jakarta : Erlangga.

Ibrahim, Jhony. 2013. Teori dan Metodologi Penelitian Hukum Normatif. Malang : Bayumedia Publishing.

Mahmud Marzuki, Peter. 2009. Penelitian Hukum, Cet. 5, Edisi Pertama. Jakarta : Interpratama Offset.

Margono, Suyud. 2001. Hak Kekayaan Intelektual Komentar atas Undang-undang Rahasia Dagang, Desain Industrti, Desain Tata Letak Sirkuit Terpadu. Jakarta : CV. Novindo 
Pustaka Mandiri.

Margono, Suyud. 2010. Aspek Hukum Komersialisasi Asset Intelektual. Bandung : Nuansa Aulia.

Munandar, Haris M.A., Sally Sitanggang. 2011. Mengenal HAKI-Hak Kekayaan Intelektual. Jakarta : Erlangga.

Philipus, M. Hadjon. 1987. Perlindungan Bagi Rakyat diIndonesia. Surabaya : PT.Bina Ilmu.

Ramdlon, Naning. 1997. Perihal Hak Cipta Indonesia Tinjauan Terhadap Auteursrecht 1912 Dan Undang-Undang Hak Cipta 1997. Yogyakarta : Liberty.

Saidin. 1997. Aspek Hukum Hak Kekayaaan Intelektual (Intelecctual Property Rights). Jakarta : Raja Grafindo Persada.

Soeharto, M. 1986. Belajar Membuat Lagu. Jakarta : PT. Gramedia.

Soelistyo, Henry. 2011. Hak Cipta Tanpa Hak Moral. Jakarta : Raja Grafindo Persada.

Supramono, Gatot. 2010. Hak Cipta dan Aspek-aspek Hukumnya Jakarta : Rineka Cipta.

Aditya,A.A.P.G.I.,\&Sukranatha,K.A.A. Perlindungan Hak Terkait Sehubungan Dengan Cover Version Lagu Berdasarkan Undang-Undang Hak Cipta. (Jurnal Ilmu Hukum, 2018)

Kusdianti Annantasari, Budi Santoso, Sartika Nanda Lestari. Implementasi perlindungan undang-undang Hak Cipta terhadap pembajakan perangkat lunak di Indonesia. (Jurnal Strata 1 (satu) Hukum Universitas Dipenogoro, 2016).

Mahmuda Pancawisma Febriharini. Eksistensi Hak Atas Kekayaan Intelektual Terhadap Hukum Siber.(Jurnal Ilmiah, Fakultas Hukum, Universitas 17 Agustus 1945 Semarang, Semarang).

P.Dina Amanda Suwari. Perlindungan Hukum terhadap lagu yang diunggah tanpa izin pencitpta di youtube. (Jurnal Ilmiah Bisnis, Fakultas Hukum Universitas Udayana).

Revian tri pamungkas, Djulaeka.Perlindungan Hukum Pemegang Hak Cipta atas lagu yang diunggah pada aplikasi TikTok. (Jurnal Ilmiah, Fakultas Hukum, Universitas Trunojoyo,2019).

Si Luh Dwi Virgiani Irmayanti. Upaya Perlindungan Hukum Bagi Pencipta Lagu Terkait 
Unggahan Cover Version pada situs Soundcloud. (Jurnal Ilmiah Hukum Bisnis, Universitas Udayana).

Tommy Hottua Marbun. Perlindungan Hukum Hak Cipta terhadap karya cipta lagu dan musik dalam bentuk ringtone pada telepon seluler. (Jurnal ilmiah Hukum Ekonomi, Fakultas Hukum, 2013).

Undang-Undang Dasar Negara Republik Indonesia tahun 1945, Kitab Undang - Undang Hukum Perdata

Undang-Undang No.28 Tahun 2018 tentang Hak Cipta (Lembaran Negara Republik Indonesia Tahun 2014 Nomor 266, Tambahan Lembaran Negara Republik Indonesia Nomor 5599). 